Vol. 2 No. 1 Januari 2022 e-ISSN : 2774-6283 | p-ISSN : 2775-0019

\title{
PENERAPAN PROJECT BASED LEARNING UNTUK MENINGKATKAN MOTIVASI BELAJAR PRODUK KREATIF DAN KEWIRAUSAHAAN PADA PESERTA DIDIK KELAS XI.TKJ 1. SMK NEGERI 1 PEMALANG
}

\author{
KARNOTO \\ SMK Negeri 1 Pemalang \\ email : karnoto.se@gmail.com
}

\begin{abstract}
ABSTRAK
Penelitian ini dilakukan dengan tujuan untuk meningkatkan motivasi belajar Produk Kreatif Dan Kewirausahaan melalui implementasi model pembelajaran berbasis proyek yaitu project based learning (PjBL) pada peserta didik kelas XI TKJ. 1. Model PBL adalah model pembelajaran yang bersifat kontekstual dengan menggunakan proyek sebagai media sehingga diharapkan dapat merubah cara belajar peserta didik secara mandiri dengan meningkatkan motivasi belajar peserta didik. Penelitian ini merupakan action research (penelitian tindakan kelas) yang terditi dari dua siklus. Model pembelajaran ini dilakukan dengan langkah-langkah; a) merancang pertanyaan yang mendasar, b) menyusun perencanaan proyek, c) menjalankan kegiatan proyek, d) memantau perkembangan proyek, e) membuat penilaian terhadap proyek, f) mengevaluasi. Kesimpulan dalam penelitian ini menunjukkan bahwa model pembelajaran PBL telah terbukti dapat meningkatkan motivasi belajar Produk Kreatif dan Kewirausahaan peserta didik sebesar $8 \%$ yaitu $77 \%$ ada siklus 1 dan meningkat $85 \%$ pada siklus 2 . Oleh karena itu, project based learning disarankan untuk diterapkan dalam pembelajaran Produk Kreatif Dan Kewirausahaan.
\end{abstract}

Kata Kunci : problem-based learning (PBL), motivasi belajar.

\section{ABSTRACT}

This research was conducted with the aim of increasing the motivation to learn Creative Products and Entrepreneurship through the implementation of a project-based learning model, namely project based learning (PjBL) in class XI. TKJ.1 students. The PBL model is a contextual learning model using projects as a medium so that it is expected to change the way students learn independently by increasing students' learning motivation. This research is an action research (classroom action research) which consists of two cycles. This learning model is carried out in steps; a) designing basic questions, b) preparing project plans, c) carrying out project activities, d) monitoring project progress, e) making an assessment of the project, f) evaluating. The conclusion in this study shows that the PjBL learning model has been proven to increase students' motivation to learn Creative Products and Entrepreneurship by $8 \%$, namely $77 \%$ in cycle 1 and an increase of $85 \%$ in cycle 2 . Therefore, project based learning is recommended to be applied in learning. Creative And Entrepreneurial Products.

Keywords: problem-based learning (PBL), learning motivation.

\section{PENDAHULUAN}

Dalam proses pendidikan terlibat berbagai input seperti sarana dan fasilitas, bahan ajar, tenaga pendidik dan kependidikan, manajemen dan tata kelola dan sumber daya lainnya serta penciptaan suasana yang kondusif baik dalam ruang lingkup akademis maupun non akademis dalam suasana yang mendukung proses pembelajaran

Proses pembelajaran diharapkan sesuai dengan PP No.19 tentang SNP tahun 2005, yakni proses pembelajaran disekolah diselenggarakan secara interaktif, inspiratif, menyenangkan, menantang, dan memotivasi Peserta Didik untuk berpartisipasi aktif, serta memberikan ruang yang cukup bagi prakarsa, kreativitas, dan kemandirian sesuai dengan bakat, minat, dan perkembangan fisik serta psikologis Peserta Didik tersebut. Hal ini dapat mengindikasikan bahwa guru sebagai pelaku proses pembelajaran di kelas, harus mampu merencanakan strategi pembelajaran, agar pembelajaran yang dilaksanakan dikelas dapat berjalan dengan baik. . 
Salah satu faktor yang ikut menentukan kelancaran peserta didik dalam belajar adalah motivasi belajar. Menurut Indaryati $(2015,88)$ motivasi adalah salah satu penggerak dari dalam hati individu untuk mencapai suatu tujuan. Motivasi belajar peserta didik dapat dipupuk dengan mengikut sertakan pesreta didik secara aktif dalam proses pembelajaran. Motivasi sangat dibutuhkan seseorang karena motivasi sebagai pemicu manusia untuk melakukan perbuatan, menentukan arah, dan menyeleksi perbuatan (Pratiwi, 2015).

Guru harus menyadari bahwa setiap Peserta Didik dalam suatu kelas memiliki kemauan dan minat yang berbeda-beda terhadap proses pembelajaran, bahkan ada juga Peserta Didik yang kehilangan minat dalam belajar. Dengan demikian, guru harus mampu mendorong dan membangkitkan semangat Peserta Didik untuk dapat mengikuti proses pembelajaran yang sedang berlangsung.

De Decce \& Grawford mengatakan bahwa motivasi belajar Peserta Didik harus senantiasa ditumbuhkan dan dipelihara pada diri Peserta Didik sebagaimana fungsi dari motivasi belajar yaitu guru harus dapat membangkitkan semangat Peserta Didik dalam belajar, memberikan harapan yang nyata, memberi insentif, dan mengarahkan Peserta Didik pada perilaku yang sesuai dengan tujuan yang telah ditetapkan (dalam Djamarah, 2011).

Hull (dalam Suciati, dkk., 2007, hlm. 3.3) menyatakan bahwa "Motivasi sebagai dorongan untuk memenuhi atau memuaskan kebutuhan agar tetap hidup". Sementara menurut Pintrich, bahwa motivasi mengacu pada apa yang membuat individu bergerak ke arah kegiatan dan tugas tertentu (dalam Djamarah, 2011). Kekuatan yang mendorong kegiatan individu disebut dengan motivasi, hal tersebut ditunjukkan dengan suatu kondisi dalam diri individu yang dapat mendorong dan menggerakkan dirinya untuk melakukan suatu kegiatan tertentu dalam mencapai tujuan (dalam Sukmadinata, 2005). Dengan demikian, dapat disimpulkan bahwa motivasi merupakan segala hal seperti dorongan yang dapat menggerakkan seorang individu untuk terus bertindak sesuai dengan apa yang dibutuhkan dalam mencapai tujuan.

Berdasarkan data pengamatan pembelajaran dan hasil wawancara dengan guru Produk Kreatif dan Kewirausahaan lainnya di SMK Negeri 1 Pemalang, masih banyak Peserta Didik yang lemahnya motivasi diri untuk belajar. Terlihat masih kurangnya persiapan Peserta Didik ketika waktu pelajaran Produk Kreatif dan Kewirausahaan dimulai di kelas, sehingga proses pembelajaran sering terlambat karena Peserta Didik dengan sengaja mengulur waktu untuk masuk ke ruang kelas. Meskipun setiap Peserta Didik sudah mempunyai sumber belajar (buku paket Produktif TKJ), akan tetapi mereka masih saja ada yang lupa membawanya ataupun mereka membawanya tapi hanya dibawa saja, tidak mencoba untuk memahaminya. Peserta Didik yang menghabiskan tidur selama jam pelajaran berlangsung, Peserta Didik mengabaikan penjelasan guru, Peserta Didik lebih asyik dengan gawai ketimbang membaca buku, dan lainlain. Jika kondisi tersebut dibiarkan, maka akan menimbulkan dampak yang kurang baik bagi Peserta Didik.

Berkaitan dengan pentingnya motivasi belajar dalam suatu pembelajaran, guru memerlukan suatu pendekatan pembelajaran yang mampu mengaktifkan motivasi belajar tersebut. Menurut penelitian Hartono dan Noto (2017) menerapkan model pembelajaran merupakan salah satu cara dalam menanggulangi masalah kesulitan belajar dan memahami konsep.

Diantara antara model-model pembelajaran yang dapat digunakan adalah model berbasis proyek yang disebut model pembelajaran project based learning (PBL ). Model project based learning merupakan model pembelajaran yang menitik beratkan pada penciptaan produk dengan melibatkan peserta didik secara langsung dalam proses pembelajarannya. sebagaimana penelitian yang dilakukan oleh Saefudin (2018) menyatakan bahwa pembelajaran langsung lebih efektif digunakan untuk mengembangkan kemampuan berkomunikasi peserta didik.

\section{METODE PENELITIAN}

Jenis penelitian yaitu penelitian tindakan kelas (PTK). Metode penelitian yang dilakukan dalam penelitian ini adalah metode penelitian deskriptif. Variabel penelitian ini 
adalah Motivasi belajar, hasil belajar dan Model Problem Based Learning. Bentuk penelitian ini adalah Penelitian Tindakan Kelas Kolaboratif yang bekerjasama dengan guru Produk Kreatif dan Kewirausahaan yang mengajar di kelas XI TKJ SMK Negeri 1 Pemalang. Pelaksanaan penelitian ini mengikuti tahap-tahap PTK yang pelaksanaannya terdiri dari dua siklus, masingmasing siklus terdiri dari tiga kali pertemuan dan satu kali ulangan harian. Arikunto (2014) mengemukakan bahwa setiap siklus terdiri dari empat tahap (perencanaan, pelaksanaan, pengamatan, dan refleksi).

Dalam penelitian ini dilakukan analisis deskriptif. Analisis deskriptif dilakukan terhadap hasil angket yang ditujukan kepada peserta didik sehingga dapat diketahui bagaimanakah peningkatan motivasi belajar Produk Kreatif dan Kewirausahaan dengan penggunaan model Project Based Learning. Penelitian ini digunakan analisis dengan persentase. Persentase skor dapat diketahui dengan membaca isian yang ada di lembar instrument. Dapat dipastikan semakin tinggi presentase suatu pernyataan atau indikator maka semakin besar tingkat keterlaksanaan.

\section{HASIL DAN PEMBAHASAN}

\section{Hasil}

Untuk mengetahui gambaran dan peningkatan motivasi belajar Peserta Didik di kelas, dibutuhkan data motivasi awal dan motivasi akhir Peserta Didik. Rata-rata motivasi awal Peserta Didik di kelas sebelum dilaksanakan tindakan adalah sebesar $73 \%$ sedangkan rata-rata motivasi seelah dilakukan Pemelajaran model Project Based Learning pada Siklus 1 adalah sebesar $77 \%$, sedangkan rata-rata motivasi Peserta Didik pada Siklus 2 adalah sebesar $85 \%$ dengan skor maksimal 100,00 dari jumlah Peserta Didik sebanyak 36 orang. Peningkatan motivasi belajar Peserta Didik di kelas dengan menerapkan pendekatan Project Based Learning sebesar 7,19. Untuk lebih jelasnya dapat dilihat dalam tabel dan grafik di bawah ini

Tabel 1. Presentase Nilai Motivasi Belajar Produk Kreatif dan Kewirausahaan dalam penerapan model Project Based Learning siklus 1.

\begin{tabular}{|c|l|c|}
\hline No & \multicolumn{1}{|c|}{ Indikator motivasi belajar } & Persentase (\%) \\
\hline 1 & Hasrat dan keinginan berhasil & $77 \%$ \\
\hline 2 & Harapan dan cita-cita & $71 \%$ \\
\hline 3 & Dorongan kebutuhan belajar & $78 \%$ \\
\hline 4 & Penghargaan saat belajar & $77 \%$ \\
\hline 5 & Kegiatan belajar yang menarik & $82 \%$ \\
\hline 6 & Lingkungan belajar mendukung & $75 \%$ \\
\hline \multicolumn{2}{|c|}{ Rata - rata } & $77 \%$ \\
\hline
\end{tabular}

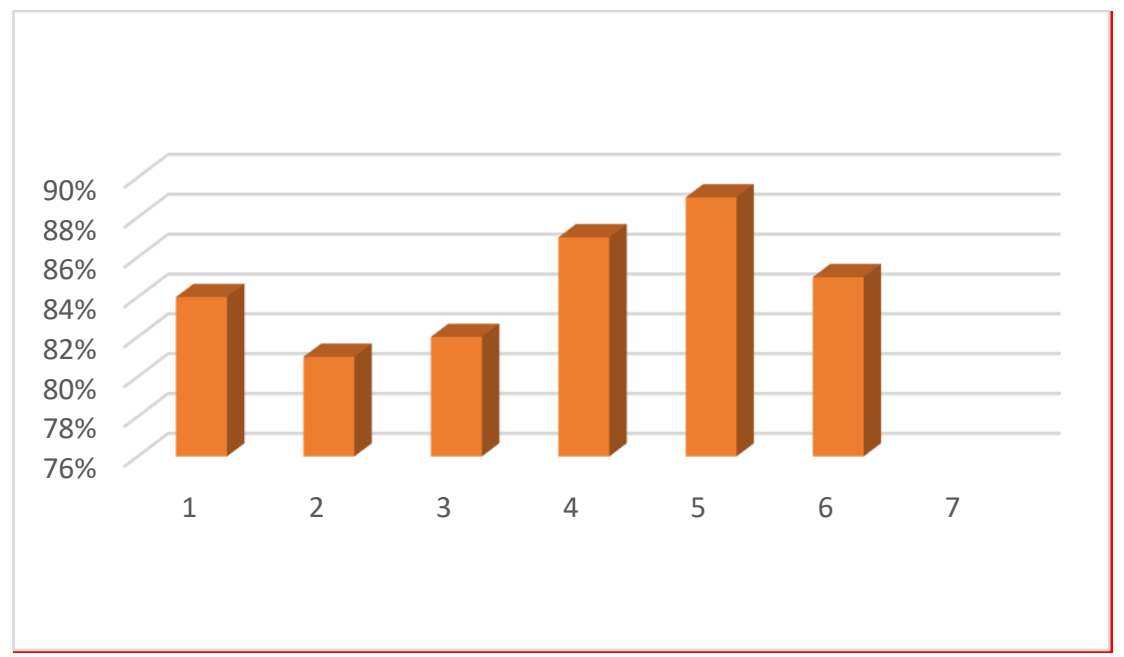

Gambar 1. Presentase nilai motivasi belajar Produk Kreatif dan Kewirausahaan dalam penerapan model Project Based Learning siklus 1. 
Vol. 2 No. 1 Januari 2022 e-ISSN : 2774-6283 | p-ISSN : 2775-0019

Tabel 2. Presentase nilai motivasi belajar Produk Kreatif dan Kewirausahaan dalam penerapan model Project Based Learning siklus 2.

\begin{tabular}{|c|l|c|}
\hline \multirow{2}{*}{ No } & \multicolumn{1}{|c|}{ Indikator motivasi belajar } & Persentase (\%) \\
\hline 1 & Hasrat dan keinginan berhasil & $84 \%$ \\
\hline 2 & Harapan dan cita-cita & $81 \%$ \\
\hline 3 & Dorongan kebutuhan belajar & $82 \%$ \\
\hline 4 & Penghargaan saat belajar & $87 \%$ \\
\hline 5 & Kegiatan belajar yang menarik & $89 \%$ \\
\hline 6 & Lingkungan belajar mendukung & $85 \%$ \\
\hline \multicolumn{2}{|c|}{ Rata - rata } & $85 \%$ \\
\hline
\end{tabular}

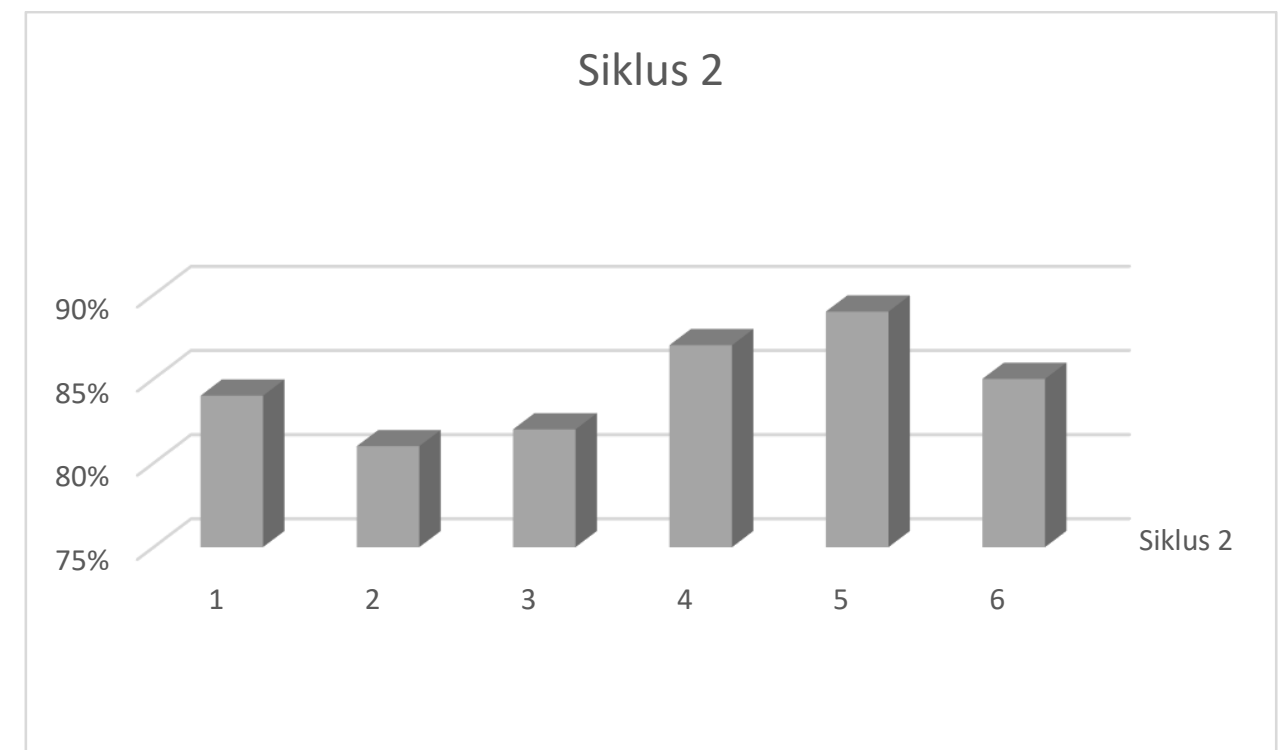

Gambar 2. Presentase nilai motivasi belajar Produk Kreatif dan Kewirausahaan dalam penerapan model Project Based Learning siklus 2

Tabel 3. Presentase kenaikan Motivasi Belajar Produk Kreatif dan Kewirausahaan dalam penerapan model Project Based Learning

\begin{tabular}{|c|l|c|c|c|}
\hline \multirow{2}{*}{ No } & \multirow{2}{*}{ Indikator motivasi belajar } & \multicolumn{3}{|c|}{ Persentase (\%) } \\
\cline { 3 - 5 } & & Awal & Siklus 1 & Siklus 2 \\
\hline 1 & Hasrat dan keinginan berhasil & $73 \%$ & $77 \%$ & $84 \%$ \\
\hline 2 & Harapan dan cita-cita & $69 \%$ & $71 \%$ & $81 \%$ \\
\hline 3 & Dorongan kebutuhan belajar & $76 \%$ & $78 \%$ & $82 \%$ \\
\hline 4 & Penghargaan saat belajar & $72 \%$ & $77 \%$ & $87 \%$ \\
\hline 5 & Kegiatan belajar yang menarik & $79 \%$ & $82 \%$ & $89 \%$ \\
\hline 6 & Lingkungan belajar mendukung & $71 \%$ & $75 \%$ & $85 \%$ \\
\hline \multicolumn{2}{|c|}{ Rata - rata } & $73 \%$ & $77 \%$ & $85 \%$ \\
\hline
\end{tabular}




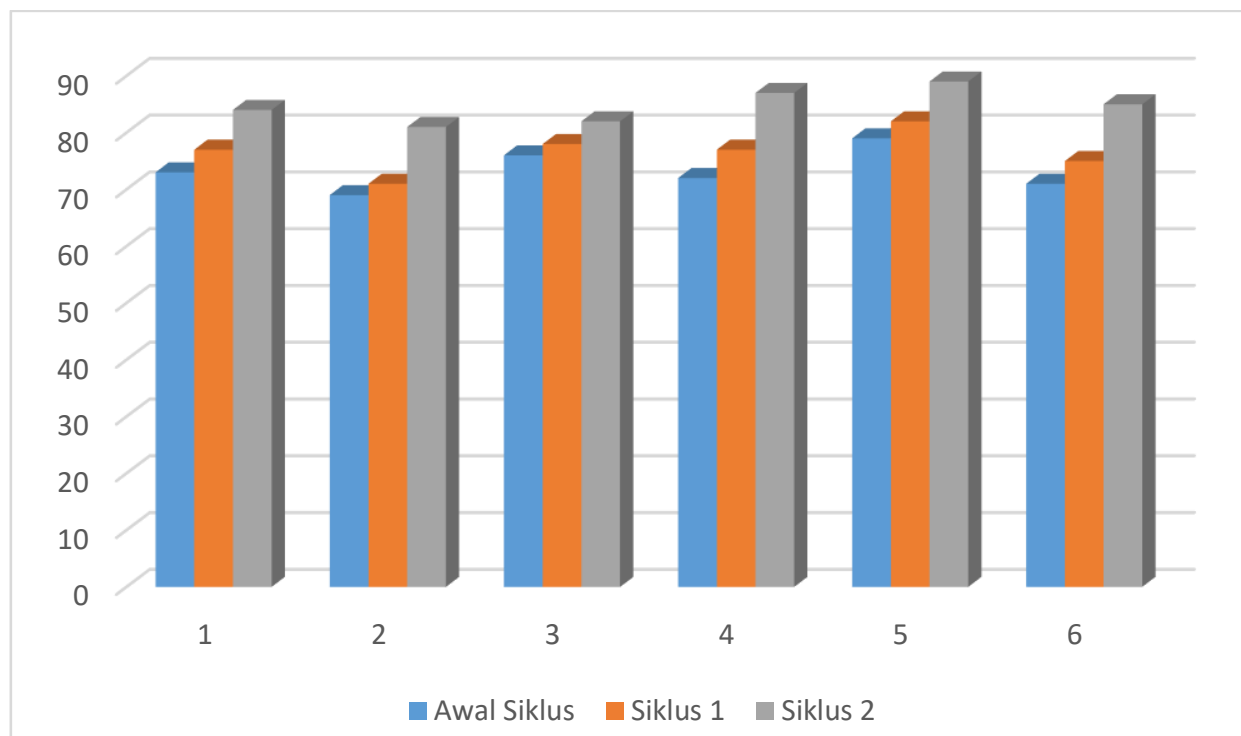

\section{Gambar 3. Presentase kenaikan motivasi belajar Produk Kreatif dan Kewirausahaan dalam penerapan model Project Based Learning}

Secara umum hasil penelitian menunjukkan adanya peningkatan motivasi belajar Produk Kreatif dan Kewirausahaan dalam penenerapan model Project Based Learning dengan presentase kenaikan sebesar 6,5\% yang ditunjukkan dengan presentase pada Awal sebelum dilaksanakan pembelajaran model Project Based Learning dilanjut pada siklus 1 memperoleh $77 \%$ dengan kategori baik kemudian meningkat pada siklus 2 menjadi $85 \%$ dengan kategori baik.

Secara khusus hasil penelitian dirinci menjadi enam indikator diantaranya: 1) hasrat keinginan berhasil; 2) harapan dan cita-cita; 3) dorongan dan kebutuhan dalam belajar; 4) penghargaan saat belajar; 5) kegiatan belajar yang menarik; 6) lingkungan belajar yang mendukung.

\section{Pembahasan}

Berdasarkan hasil belajar, angket motivasi belajar serta observasi tindakan pada siklus 1, selanjutnya dilakukan refleksi bersama tim kolaborator. Kekurangan yang ditemui pada siklus 1 diperbaiki pada siklus 2.

Peningkatan yang terjadi pada siklus 2 menunjukkan angka yang berbeda-beda pada masing-masing indikator. Indikator pertama mengenai adanya hasrat dan keinginan berhasil memperoleh presentase pada siklus 2 sebesar $84 \%$ dengan kategori sangat baik, kemudian pada indikator adanya harapan dan cita-cita masa depan memperoleh kategori baik dengan presentase yang meningkat menjadi $81 \%$, pada indikator ketiga memperoleh presentase $82 \%$ dengan kategori baik dengan indikator dorongan dan kebutuhan dalam belajar. Pada indikator adanya penghargaan dalam belajar memperoleh presentase sebesar $87 \%$ dengan kategori sangat baik. Pada indikator kelima mengenai adanya kegiatan yang menarik dalam belajar menperoleh presentasi sebesar $89 \%$ dengan kategori sangat baik. Kemudian pada indikator terahir yaitu adanya lingkungan belajar yang kondusif memperoleh presentase sebesar $85 \%$ dengan kategori sangat baik.

Presentase peningkatan dari siklus 1 ke siklus 2 menunjukkan perbedaan pada setiap indikator. Indikator pertama adanya hasrat dan keinginan berhasil memperoleh presentase kenaikan dari siklus 1 ke siklus 2 sebesar 7\%. Indikator adanya harapan serta cita-cita masa depan memperoleh presentase kenaikan sebesar $10 \%$. Indikator ketiga menunjukkan presentase kenaikan sebesar 4\% mengenai adanya dorongan dan kebutuhan dalam belajar. Indikator keempat adanya penghargaan dalam belajar memperoleh presentase kenaikan dari siklus $1 \mathrm{ke}$ silus 2 sebanyak 10\%. Pada indikator kelima menunjukkan kenaikan dengan presentase $7 \%$ 
yaitu mengenai adanya kegiatan yang menarik dalam belajar. Indikator terahir mengenai adanya lingkungan belajar yang kondusif memperoleh presentase kenaikan sebesar $8 \%$.

Pada kondisi awal sebelum dilakukan tindakan, rata - rata motivasi Peserta Didik dalam belajar Produk Kreatif dan Kewirausahaan sebesar 73\%. Pada saat diberi penenerapan model Project Based Learning rata - rata motivasi Peserta Didik dalam belajar Produk Kreatif dan Kewirausahaan sebesar 85\% . Hal ini sesuai dengan Chakravarthi (2010) yang menyimpulkan bahwa ada manfaat yang jelas bagi Peserta Didik dari penggunaan format Project Based Learning, berpikir kritis, dan pemecahan masalah. Hasil penelitian ini dapat dimaknai bahwa hasil belajar perlu diperhatikan karena sebagai tolak-ukur keberhasilan pembelajaran.

Meece \& Blumenfeld menyatakan bahwa terdapat interaksi antara cara mengajar guru dengan pola motivasi Peserta Didik . Membuat suatu hal yang menarik, menantang Peserta Didik untuk berpikir kemudian memecahkan masalah, sehingga Peserta Didik berperan aktif dalam proses belajar merupakan cara guru mengajar yang dapat membuat motivasi belajar Peserta Didik menjadi meningkat. Sebaliknya ketika guru mengajar dengan tidak semangat, tidak kreatif, cenderung membosankan dan membuat Peserta Didik tidak nyaman berada di kelas dapat membuat motivasi Peserta Didik menjadi rendah. Kemudian Ames \& Archer mengungkapkan bahwa guru dapat mengubah dan meningkatkan motivasi belajar Peserta Didik , dengan guru melakukan tindakan tertentu di dalam kelas sehingga membangkitkan minat, semangat dan motivasi belajar Peserta Didik (dalam Suciati, dkk., 2007).

Berdasarkan pemaparan diatas, penerapan model project based learning dapat meningkatkan motivasi belajar matematika peserta didik dan sudah memenuhi indikator keberhasilan. Hal tersebut berdampak pula pada meningkatnya hasil tes formatif yang dikerjakan peserta didik secara mandiri pada akhir pembelajaran. Selain meningkatnya hasil belajar, penggunaan model problem based learning dalam pembelajaran matematika juga memberikan dampak pengiring, diantaranya: (1) kreativitas, kemampuan berpikir kritis, kemampuan berkolaborasi, dan kemampuan berkomunkasi peserta didik terbangun dengan adanya proyek yang harus mereka kerjakan; (2) meningkatnya kemampuan mengorganisir kelompok karena peserta didik harus dapat mengatur pembagian tugas agar proyek dapat terselesaikan dengan baik; (3) menumbuhkan jiwa kompetitif antar peserta didik supaya menjadi kelompok yang terbaik; dan (4) pembelajaran lebih bermakna dan memberikan arti mendalam bagi peserta didik dan guru.

Dalam pembelajaran dengan menggunakan pendekatan Project Based Learning, Peserta Didik ditantang untuk menyelesaikan masalah secara mandiri dalam kelompok. Hal tersebut dapat menarik minat Peserta Didik untuk dapat menyelesaikan masalah berkaitan dengan masalah yang relevan dan sesuai dengan kehidupan Peserta Didik sehari-hari, sehingga ketika Peserta Didik mampu menyelesaikan masalah tersebut, Peserta Didik akan mendapatkan kebermanfaatan dalam belajar, dengan harapan penyelesaian masalah di kelas dapat menjadi bekal bagi Peserta Didik dalam menyelesaikan masalah yang nyata di kehidupan sehari-hari dan benar-benar dialami oleh Peserta Didik secara langsung. Kondisi yang mempengaruhi sikap dan motivasi belajar yaitu ketika Peserta Didik mandiri dalam belajar (self-regulated), hal tersebut senada dengan salah satu karakteristikpendekatan Project Based Learning yaitu new information is acquired through self-directed learning.

Selain itu, juga dapat melatih peserta didik dalam meningkatkan kemampuan 4C (Creativity, Critical Thinking, Colaborative, Communication). Bagian yang penting adalah terwujudnya peserta didik yang memenuhi kriteria HOTS (High Thinking Order Skills). Untuk mewujudkan peserta didik yang HOTS, perlu halnya untuk dimulai dari guru yang HOTS terlebih dahulu. Guru merancang pembelajaran sesuai kompetensi dasar dan tujuan yang hendak dicapai dan menentukan indikator dengan tingkatan HOTS, yaitu menganalisis, mengevaluasi, dan mencipta. 


\section{KESIMPULAN}

Perbaikan pembelajaran melalui penerapan model Problem Based Learning dalam proses pembelajaran Produk Kreatif dan Kewirausahaan. Hal tersebut ditunjukkan oleh hasil angket yang menunjukkan pada presentase pada siklus 1 sebesar $77 \%$ dan mengalami peningkatan pada siklus dua menjadi $85 \%$. Selain itu project based learning memberikan dampak positif bagi guru dan peserta didik, antara lain kreatifitas peserta didik terbangun dengan adanya proyek yang harus mereka kerjakan; meningkatnya kemampuan mengorganisir kelompok karena peserta didik harus dapat mengatur pembagian tugas agar proyek dapat diselesaikan dengan baik; menumbuhkan jiwa kompetitif antar peserta didik supaya menjadi kelompok yang terbaik; dan pembelajaran lebih bermakna dan memberikan arti mendalam bagi peserta didik dan guru.

Berdasarkan simpulan diatas, project based learning dapat diterapkan dalam pembelajaran Produk Kreatif dan Kewirausahaan. Karena memenuhi tuntutan pembelajaran kurikulum 2013 antara lain pendekatan saintifik, 4C, HOTS, dan PPK.

\section{DAFTAR PUSTAKA}

Ames, C., \& Archer, J. (1988). Achievement goals in the classroom: Students' learning strategies and motivation processes. Journal of Educational Psychology, 80(3), 260267. https://doi.org/10.1037/0022-0663.80.3.260

Arikunto, Suharsimi. 2014. Prosedur Penelitian Suatu Pendekatan Praktik. Jakarta : Rineka Cipta

Djamarah, S. B. (2011). Psikologi belajar. Jakarta: Rineka Cipta.

Indaryati, Jailani (2015). Pengembangan Media Komik Pembelajaran Matematika Meningkatkan Motivasi Dan Prestasi Belajar Peserta Didik Kelas V Jurnal Prima Edukasia, Volume 3 - Nomor 1, 2015

Kemendikbud. (2013). Materi Pelatihan Guru Implementasi Kurikulum 2013. Badan Pengembangan Sumber Daya Manusia Pendidikan dan Kebudayaan dan Penjaminan Mutu Pendidikan Kementerian Pendidikan dan Kebudayaan

Ratnasari, S. F., dan A. A. Saefudin. (2018). Efektivitas pendekatan contextual teaching andLearning (CTL) ditinjau dari kemampuan Komunikasi matematika Peserta Didik. Jurnal Matematika dan Pembelajaran. Vol.6, No.1, 119-127. Diakses di

Srikumar Chakravarthi and Nagaraja Haleagrahara, 2011. A Comprehensive Review of the Occurrence and Management of Systemic Candidiasis as an Opportunistic Infection. Microbiology Journal, 1: 1-7.

Suciati, dkk. (2007). Materi pokok belajar dan pembelajaran. Jakarta: Universitas Terbuka.

Sukmadinata, N. S. (2005). Landasan psikologi proses pendidikan. Bandung: PTRemaja Rosdakarya. 